Portland State University

PDXScholar

\title{
The E-Bike Potential: Estimating the Effect of E-Bikes on Person Miles Travelled and Greenhouse Gas Emissions
}

\author{
Michael McQueen \\ Portland State University \\ John MacArthur \\ Portland State University, macarthur@pdx.edu \\ Christopher Cherry \\ University of Tennessee, Knoxville
}

Follow this and additional works at: https://pdxscholar.library.pdx.edu/trec_reports

Part of the Transportation Commons, Urban Studies Commons, and the Urban Studies and Planning Commons

Let us know how access to this document benefits you.

\author{
Recommended Citation \\ McQueen, M., MacArthur, J., and Cherry, C. The E-Bike Potential: Estimating the Effect of E-Bikes on \\ Person Miles Travelled and Greenhouse Gas Emissions. Portland, OR: Transportation Research and \\ Education Center (TREC), 2019. https://doi.org/10.15760/trec.242
}

This Report is brought to you for free and open access. It has been accepted for inclusion in TREC Final Reports by an authorized administrator of PDXScholar. Please contact us if we can make this document more accessible: pdxscholar@pdx.edu. 


\section{曲TREC}

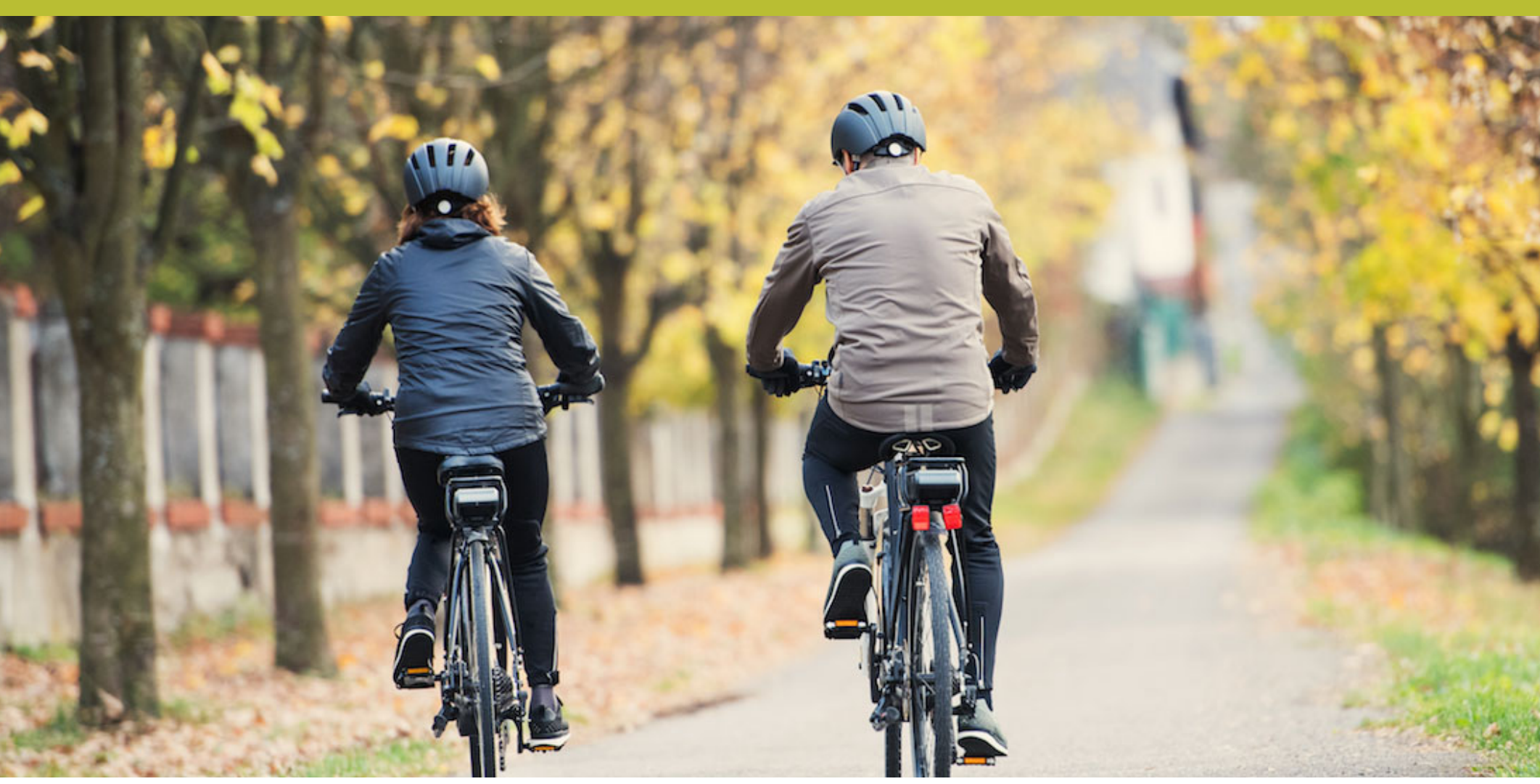

The E-Bike Potential: Estimating the Effect of E-Bikes on Person Miles Travelled and
Greenhouse Gas Emissions

Michael McQueen John MacArthur Christopher Cherry, PhD

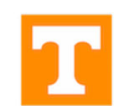

THE UNIVERSITY OF TENNESSEE KNOXVILLE

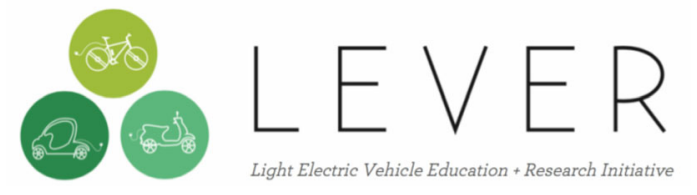

龟 Portland State 


\title{
The E-Bike Potential: Estimating the Effect of E-bikes On Person Miles Travelled and Greenhouse Gas Emissions
}

\section{A WHITE PAPER \\ MAY 2019}

\author{
Michael McQueen \\ John MacArthur \\ Transportation Research and Education Center \\ Portland State University \\ Christopher Cherry, PhD \\ University of Tennessee, Knoxville
}




\section{ACKNOWLEDGEMENTS}

This material was primarily funded with a grant from the Bicycle Product Suppliers Association (BPSA) and PeopleForBikes, and is based upon work supported by the National Science Foundation under Grant No. 1706695. Any opinions, findings, and conclusions or recommendations expressed in this material are those of the author(s) and do not necessarily reflect the views of the National Science Foundation. This paper was prepared by the Transportation Research and Education Center (TREC) at Portland State University, and lead by research team members behind the LEVER Initiative.

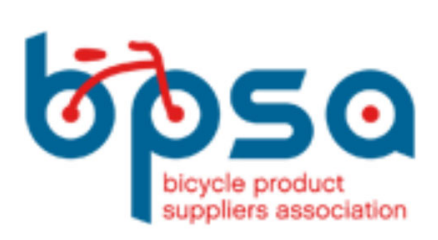

\section{ABOUT TREC}

The Transportation Research and Education Center (TREC) at Portland State University (PSU) is first and foremost an interdisciplinary center. Our research initiatives combine the voices and expertise of a wide range of backgrounds that collectively shape the ways we move through the world. We support collaborative research and education that provide a unique lens on transportation insight for vibrant communities. TREC is home to the U.S. DOT funded National Institute for Transportation and Communities (NITC) consortium, the Initiative for Bicycle and Pedestrian Innovation (IBPI), and other transportation grants and programs. We produce impactful research for transportation decision makers, and support the education of future transportation professionals through curriculum development and student participation in research.

trec.pdx.edu

\section{ABOUT LEVER}

The Light Electric Vehicle Education and Research (LEVER) Initiative is a consortium of Light Electric Vehicle (LEV) researchers and educators that currently includes faculty and staff from University of Tennessee, Portland State University, and Monash University. LEVER started in 2014 to bring together some of the leading researchers in the field to collectively answer some of the biggest questions related to these emerging vehicles. The mission of the LEVER is to bring a collective focus through interdisciplinary research directed at LEV adoption, system integration, societal impacts, and related policy. UTK's LEVER center will initiate the formation an international cooperative research center on LEVs, bridging academia, industry, government, and nongovernment organizations. www.levresearch.com 


\section{INTRODUCTION}

Many cities have goals for reducing automotive VMT in order to reduce tailpipe emissions and to reduce congestion. Conventional cycling is a good solution, though its uptake has slowed in recent years in several cities, despite the implementation of greenways, bikeshare, and bike lines (Anderson and McLeod 2017). Electric bicycles (e-bikes) could be an effective new part of the solution to combat mode shift stagnation.

The e-bike is a recently introduced mode of travel that is rapidly gaining in popularity throughout the United States. The e-bike can offer a cheaper alternative to car travel (Popovich et al. 2014) and can provide users with an adequate level of physical activity intensity necessary to enhance health (Fishman and Cherry 2016). Riding an e-bike is rewarding and fun, is freeing for users with limited ability and mobility, and can even lead to a car-free household (Popovich et al. 2014; MacArthur et al. 2017, 2018; Jones, Harms, and Heinen 2016). It can be a useful tool to reduce $\mathrm{CO}_{2}$ emissions, urban noise and air pollution, and inner city traffic (Weiss et al. 2015). Lastly, e-bikes encourage users to cycle farther and more often than conventional bicycles (MacArthur et al. 2018), meaning that they offer the opportunity to multiply the benefits already available through conventional cycling. This white paper explores the potential e-bike effect on person miles traveled (PMT) and greenhouse gas emissions $(\mathrm{GHG})$ in terms of $\mathrm{CO}_{2}$ for varying levels of e-bike mode share replacement. A model for PMT shift and GHG reduction potential is created for Portland, Oregon. Portland was selected for analysis because of the availability of regional transportation data, the extensiveness of the city's bike network that would lend itself to e-bike uptake, and the authors' familiarity with the city. 


\section{LITERATURE REVIEW}

This white paper draws on the Global High Shift Scenario project, aimed at aggregating transportation emission trends modeled country-by-country through 2050 , including both business-as-usual and high-mode-shift scenarios (Replogle and Fulton 2014). This initial study was augmented the following year to include more aggressive contributions from cycling and e-cycling as utilitarian modes of transport. The study found that a world that achieves a scenario of $14 \%$ combined bicycle and e-bike mode share by person kilometers traveled could see a $10 \%$ reduction in transportation emissions due to the immense energy required per person kilometer for light-duty passenger vehicles compared to e-bikes and bicycles (Mason, Fulton, and McDonald 2015).

The impact of transportation on the environment can also be expressed as lifecycle carbon emission rates, which take into account the emissions from manufacturing and disposal as well as usage. A report by the European Cyclists' Federation found that bicycles and e-bikes have a lifecycle emissions rate of approximately 21 grams and 22 grams of $\mathrm{CO}_{2} \mathrm{e}$ per person kilometer respectively, while public transit buses emit $101 \mathrm{~g}$ lifecycle $\mathrm{CO}_{2} \mathrm{e}$ and cars emit $271 \mathrm{~g}$ lifecycle $\mathrm{CO}_{2} \mathrm{e}$ per person kilometer (Blondel, Mispelon, and Ferguson 2011). Clearly, an increased share of bicycles and e-bikes and a decreased share of light-duty passenger vehicles on the road have the potential to greatly reduce carbon emissions.

Even with this potential, does that mean that people will actually use e-bikes to replace trips taken by more carbon emitting modes? A study in Brighton, United Kingdom found that a trial group of 80 participants that were loaned e-bikes reduced their number of miles driven by $20 \%$. Users traveled a weekly average of 15-20 miles by e-bike, with commuting coming out as the dominant trip purpose. In addition, $43 \%$ of participants reported that they travelled less as a car driver (Cairns et al. 2017). Another study in Sweden found through a survey of existing e-bike owners that e-bikes saved users an average of $55 \mathrm{~km}$ per week for cars in urban areas and $62 \mathrm{~km}$ per week for cars in rural areas. E-bike trips were also found to predominantly replace car trips compared to other modes (Hiselius and Svensson 2017). A study of North American e-bike owners found that $62 \%$ of e-bike trips replaced trips that otherwise would have been taken by car. Of these trips previously taken by car, $45.8 \%$ were commute trips to work or school, $44.7 \%$ were other utilitarian trips (entertainment, personal errands, visiting friends and family, or other), and $9.4 \%$ were recreation or exercise trips. The average length of trips otherwise taken by car was 9.3 miles (MacArthur et al. 2018). 
The analysis in this paper employs e-bike usage data uncovered by the MacArthur et al. (2018) survey results to form the basis for modeling e-bike replacement of trips and distances of other modes in Portland. Baseline transportation usage and emissions conditions for the city of Portland were obtained from the Oregon Metro Regional Transportation Plan appendices, Oregon Household Activity Survey, U.S. Energy Information Administration, U.S. Environmental Protection Agency eGrid data, and the Federal Transit Administration. 


\section{METHOD}

In order to apply the information of e-bike ridership trends gleaned in MacArthur et al. (2018) and to create a similar but smaller scale version of the 2015 High Shift Cycling Scenario report by Mason et al. for Portland, OR, we needed a tool to model PMT and GHG reduction potential due to e-bike mode share increase. The analysis was performed using a modified version of a Microsoft Excel tool developed by researchers at the Hamburg University of Technology (TUHH) Institute for Transport Planning and Logistics in conjunction with the Mobile 2020 Project, co-funded by the Intelligent Energy Europe Programme of the European Union. The goal of the Mobile 2020 Project was to develop a plan to build and maintain a strong cycling culture in Central and Eastern Europe (Rudolph 2014a). The program ran between May 2011 and April 2014, however, program information, reports, and tools are still available online (Rudolph 2014b). The model calculates PMT and carbon footprint impacts resulting from bicycle mode share variations. We augmented the tool to accommodate English units, calculate average carbon footprint per person mile for public transit, calculate total e-bike emissions, and account for reductions in trips and distance traveled of other modes given a specified increase in e-bike mode share by trips. Table 1 is the resulting input page of the augmented model. The model reduces number of trips and distance traveled by modes other than e-bikes proportional to the ratios of utilitarian trips and miles replaced by e-bikes from MacArthur et al. (2018). Trips determined to be utilitarian include trips made for commuting, running personal errands, visiting friends and family, and visiting entertainment facilities. Utilitarian trips exclude trips made for recreation and exercise purposes. Of all of the e-bike trips observed by the survey, $80 \%$ were utilitarian. Of all utilitarian e-bike trips, $67.9 \%$ would have been made by car, $12.8 \%$ by conventional cycling, $12.7 \%$ by public transit, and $6.6 \%$ by walking. Of the utilitarian miles traveled by e-bikes instead of by other modes, $72.4 \%$ would have been traveled by car, $12.2 \%$ by conventional cycling, $13.2 \%$ by public transit, and $2.2 \%$ by walking, assuming route choice is held constant. This data is stored in the "E-Bike Mode Replacement Split:" section in Table 1.

Because the model only provides results for specific e-bike mode share increases, a companion code in $\mathrm{R}$ was developed to create visualizations for a continuum of e-bike mode share increase values. These tools can be used to estimate PMT shift and GHG reductions for any region as long as all required input data is available. The input data sources and the calculations performed to find potential PMT shift and GHG reductions for Portland from ebikes can be found in the Appendix. 


\section{Table 1: Model Input Data}

\section{CO2 Estimation}

Input

country: city:

\begin{tabular}{|l|l}
\hline USA & Portland, OR (excl. Clark County) \\
\hline
\end{tabular}

\begin{tabular}{|l|l|r|l|}
\hline \multirow{2}{*}{ city-information: } & population: & $1,605,672$ & (total) \\
\cline { 2 - 4 } & avg trips a day: & 3.8762923 & (per person) \\
\cline { 2 - 4 } & avg trip length & 4.9 & $\mathrm{mile} /$ trip \\
\hline
\end{tabular}

\begin{tabular}{|c|l|r|l|}
\hline & CO2 per gal fuel & 8572 & $\mathrm{~g} \mathrm{CO} 2 / \mathrm{gal}$ \\
\cline { 2 - 4 } & avg fuel economy & 23 & $\mathrm{mpg}$ \\
\cline { 2 - 4 } details (car): & avg occupancy Rate & 1.36 & persons/veh \\
\cline { 2 - 4 } & avg person fuel economy & 31.26 & person mpg \\
\hline \multirow{2}{*}{ details (public transit) } & avg emissions & $\begin{array}{l}\mathrm{g} \mathrm{CO} 2 / \\
\text { passenger } \\
\text { mile }\end{array}$ \\
\hline details(e-bike): & $\begin{array}{l}\text { avg emissions/mile (from } \\
\text { electricity generation) }\end{array}$ & 4.9 & $\mathrm{~g} \mathrm{CO} 2 / \mathrm{mile}$ \\
\hline
\end{tabular}

\begin{tabular}{|c|c|c|c|c|}
\hline \multirow[t]{7}{*}{ Current Modal Split: } & \multicolumn{2}{|c|}{ number of trips } & avg trip length & mile \\
\hline & car & $84.7 \%$ & car & 5.49 \\
\hline & cycling & $3.7 \%$ & cycling & 3.23 \\
\hline & public transit & $4.2 \%$ & public transit & 3.9 \\
\hline & walking & $7.4 \%$ & walking & 1.0 \\
\hline & e-bike & $0.0 \%$ & e-bike & 4.65 \\
\hline & & $100.0 \%$ & & \\
\hline
\end{tabular}

Use survey data to understand what trips are being replaced by e-bikes, entered here:

\begin{tabular}{|c|c|c|c|c|c|}
\hline \multirow{6}{*}{$\begin{array}{c}\text { E-Bike Mode } \\
\text { Replacement Split: }\end{array}$} & \multicolumn{2}{|l|}{ number of trips } & \multirow{2}{*}{\begin{tabular}{|l} 
distance disp. \\
car \\
\end{tabular}} & \multirow{2}{*}{\begin{tabular}{|r|} 
miles \\
15136 \\
\end{tabular}} & \multirow{2}{*}{$\begin{array}{r}\text { percentage } \\
72.4 \% \\
\end{array}$} \\
\hline & car & $67.9 \%$ & & & \\
\hline & cycling & $12.8 \%$ & cycling & 2543 & $12.2 \%$ \\
\hline & public transit & $12.7 \%$ & public transit & 2751 & $13.2 \%$ \\
\hline & walking & $6.6 \%$ & walking & 465 & $2.2 \%$ \\
\hline & \multicolumn{2}{|r|}{$100.0 \%$} & \multicolumn{2}{|r|}{ Sum } & $100.0 \%$ \\
\hline
\end{tabular}




\section{RESULTS}

This section presents findings from the model on the potential of e-bikes to shift PMT and GHG emissions. First, the output page from the excel version of the model is explored. Next, results are presented from the $\mathrm{R}$ code for Trips and PMT. Last, impact on GHG emissions is discussed.

In Table 2, the "input" section for the model provides a reiteration of some values from the input tab, as well as calculated values from the input data for travelled miles (total), trips (total), and mode split by travelled miles (MST). The "Effects of e-bike promotion" section is where the user can specify three scenarios of increased e-bike mode share by trips in percentage points. An increase from the given e-bike average trip length value can also be specified by percent if desired, however this feature has not been used by this analysis. The scenario 1, 2, and 3 sections provide information corresponding to the defined mode share increase specified above. Table 3 provides the initial $\mathrm{CO}_{2}$ emissions per day and per year, as well as the resulting emissions for each scenario. The difference between the before and after cases is also given for convenience. 
Table 2: Model Results

Database. Here you can see the information you entered and some calculated information.

This table is created on base on Modal Split of number of trips.

\begin{tabular}{|c|c|c|c|c|c|c|}
\hline \multirow{7}{*}{ 范 } & & Modal Split & $\begin{array}{l}\text { avg. trip } \\
\text { length }\end{array}$ & $\begin{array}{c}\text { travelled } \\
\text { miles (total) }\end{array}$ & trips (total) & $\begin{array}{l}\text { Modal Split } \\
\text { travelled miles }\end{array}$ \\
\hline & car & $84.700 \%$ & 5.49 & $28,942,038$ & $5,271,774$ & $92.8 \%$ \\
\hline & cycling & $3.70 \%$ & 3.23 & 743,837 & 230,290 & $2.4 \%$ \\
\hline & public transit & $4.200 \%$ & 3.93 & $1,027,342$ & 261,410 & $3.3 \%$ \\
\hline & walking & $7.400 \%$ & 1 & 460,580 & 460,580 & $1.5 \%$ \\
\hline & e-bike & $0.000 \%$ & 4.65 & 0 & 0 & 0 \\
\hline & & $100.0 \%$ & & $31,173,797$ & $6,224,054$ & $100.0 \%$ \\
\hline
\end{tabular}

Effect of e-bike promotion

\begin{tabular}{|l|r|r|r|}
\cline { 2 - 4 } \multicolumn{1}{c|}{} & scenario 1 & scenario 2 & \multicolumn{1}{c|}{ scenario 3 } \\
\hline expected percentage pt increase of e-bike trip & $5.0 \%$ & $10.0 \%$ & $15.0 \%$ \\
\cline { 2 - 4 } expected increase of e-bike trip length: & $0.0 \%$ & $0.0 \%$ & $0.0 \%$ \\
\hline
\end{tabular}

Changes

\begin{tabular}{|c|c|c|c|c|c|c|c|c|c|}
\hline & current status & new MS & $\begin{array}{l}\text { changes in } \\
\text { no. of trips }\end{array}$ & $\begin{array}{c}\text { no. of trips } \\
\text { new }\end{array}$ & $\begin{array}{l}\text { trip length } \\
\text { new }\end{array}$ & $\begin{array}{l}\text { travelled } \\
\text { miles new }\end{array}$ & $\begin{array}{c}\text { MS } \\
\text { travelled } \\
\text { miles new }\end{array}$ & $\begin{array}{c}\text { change MS } \\
\text { travelled } \\
\text { miles }\end{array}$ & $\begin{array}{c}\text { change in } \\
\text { travelled } \\
\text { miles }\end{array}$ \\
\hline \multirow{6}{*}{ 疍 } & car & $81.3 \%$ & - 211,307 & $5,060,467$ & 5.51 & $27,893,787$ & $89.5 \%$ & $-3.4 \%$ & $-1,048,251$ \\
\hline & cycling & $3.1 \%$ & 39,834 & 190,456 & 2.98 & 567,720 & $1.8 \%$ & $-0.6 \%$ & 176,117 \\
\hline & public transit & $3.6 \%$ & 39,523 & 221,888 & 3.77 & 836,821 & $2.7 \%$ & $-0.6 \%$ & 190,522 \\
\hline & walking & $7.1 \%$ & 20,539 & 440,041 & 0.97 & 428,376 & $1.4 \%$ & $-0.1 \%$ & 32,204 \\
\hline & e-bike & $5.0 \%$ & 311,203 & 311,203 & 4.65 & $1,447,093$ & $4.6 \%$ & $4.6 \%$ & $1,447,093$ \\
\hline & & $100.0 \%$ & 0 & $6,224,054$ & - & $31,173,797$ & $100.0 \%$ & $0.0 \%$ & - \\
\hline
\end{tabular}

\begin{tabular}{|c|c|c|c|c|c|c|c|c|c|}
\hline & current status & new MS & $\begin{array}{l}\text { changes in } \\
\text { no. of trips }\end{array}$ & $\begin{array}{c}\text { no. of trips } \\
\text { new }\end{array}$ & $\begin{array}{l}\text { trip length } \\
\text { new }\end{array}$ & $\begin{array}{l}\text { travelled } \\
\text { miles new }\end{array}$ & $\begin{array}{c}\text { MS } \\
\text { travelled } \\
\text { miles new }\end{array}$ & $\begin{array}{c}\text { change MS } \\
\text { travelled } \\
\text { miles }\end{array}$ & $\begin{array}{c}\text { change in } \\
\text { travelled } \\
\text { miles }\end{array}$ \\
\hline \multirow{6}{*}{ 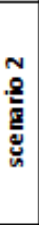 } & car & $77.9 \%$ & - 422,613 & $4,849,160$ & 5.54 & $26,845,537$ & $86.1 \%$ & $-6.7 \%$ & $-2,096,501$ \\
\hline & cycling & $2.4 \%$ & - $\quad 79,668$ & 150,622 & 2.60 & 391,604 & $1.3 \%$ & $-1.1 \%$ & 352,233 \\
\hline & public transit & $2.9 \%$ & - $\quad 79,045$ & 182,365 & 3.54 & 646,299 & $2.1 \%$ & $-1.2 \%$ & 381,043 \\
\hline & walking & $6.7 \%$ & - $\quad 41,079$ & 419,501 & 0.94 & 396,172 & $1.3 \%$ & $-0.2 \%$ & 64,408 \\
\hline & e-bike & $10.0 \%$ & 622,405 & 622,405 & 4.65 & $2,894,185$ & $9.3 \%$ & $9.3 \%$ & $2,894,185$ \\
\hline & & $100.0 \%$ & 0 & $6,224,054$ & - & $31,173,797$ & $100.0 \%$ & $0.0 \%$ & - \\
\hline
\end{tabular}

\begin{tabular}{|c|c|c|c|c|c|c|c|c|c|}
\hline & current status & new MS & $\begin{array}{l}\text { changes in } \\
\text { no. of trips }\end{array}$ & $\begin{array}{c}\text { no. of trips } \\
\text { new }\end{array}$ & $\begin{array}{l}\text { trip length } \\
\text { new }\end{array}$ & $\begin{array}{l}\text { travelled } \\
\text { miles new }\end{array}$ & $\begin{array}{c}\text { MS } \\
\text { travelled } \\
\text { miles new }\end{array}$ & $\begin{array}{c}\text { change MS } \\
\text { travelled } \\
\text { miles }\end{array}$ & $\begin{array}{c}\text { change in } \\
\text { travelled } \\
\text { miles }\end{array}$ \\
\hline \multirow{6}{*}{ 量 } & car & $74.5 \%$ & - 633,920 & $4,637,854$ & 5.56 & $25,797,286$ & $82.8 \%$ & $-10.1 \%$ & $-3,144,752$ \\
\hline & cycling & $1.8 \%$ & $-\quad 119,502$ & 110,788 & 1.95 & 215,487 & $0.7 \%$ & $-1.7 \%$ & 528,350 \\
\hline & public transit & $2.3 \%$ & - 118,568 & 142,842 & 3.19 & 455,777 & $1.5 \%$ & $-1.8 \%$ & 571,565 \\
\hline & walking & $6.4 \%$ & 61,618 & 398,962 & 0.91 & 363,969 & $1.2 \%$ & $-0.3 \%$ & 96,611 \\
\hline & e-bike & $15.0 \%$ & 933,608 & 933,608 & 4.65 & $4,341,278$ & $13.9 \%$ & $13.9 \%$ & $4,341,278$ \\
\hline & & $100.0 \%$ & 0 & $6,224,054$ & - & $31,173,797$ & $100.0 \%$ & $0.0 \%$ & - \\
\hline
\end{tabular}


Table 3: Model Results - Emissions

\begin{tabular}{|lllll|}
\hline Emissions before per day: & 8,080 & \multicolumn{3}{l|}{ tons CO/day } \\
per year: & $2,949,056$ & tons CO/year & & \\
& Scenario 1 & Scenario 2 & Scenario 3 & \\
E-bike Mode Share: & $5.0 \%$ & $10.0 \%$ & $15.0 \%$ & \\
Emissions after per day: & 7,773 & 7,466 & 7,159 & t CO/day \\
per year: & $2,837,007$ & $2,724,958$ & $2,612,909$ & t CO/year \\
Reduction of CO, per day: & 307 & 614 & 921 & t CO/day \\
per year: & 112,049 & 224,098 & 336,147 & t CO/year \\
Percent reduction & $3.8 \%$ & $7.6 \%$ & $11.4 \%$ & \\
\hline
\end{tabular}

\section{Trips and PMT}

The model was run for scenarios ranging from $0 \%$ to $15 \%$ e-bike mode share by trips. Car mode share by trips is the most dramatically affected by increases in e-bike mode share. This is attributed to the fact that MacArthur et al. (2018) found that $72.4 \%$ of e-bike utilitarian miles replaced person miles that otherwise would have been traveled by cars. So, for every 100 miles traveled by an e-bike user, 72.4 would have otherwise been driven in a car. Looking at person miles travelled per day, it is apparent that an increase in e-bike trips creates a substantial decrease in car person miles traveled. It amounts to approximately a $10 \%$ decrease in PMT by car for a 15\%-point increase in e-bike mode share.

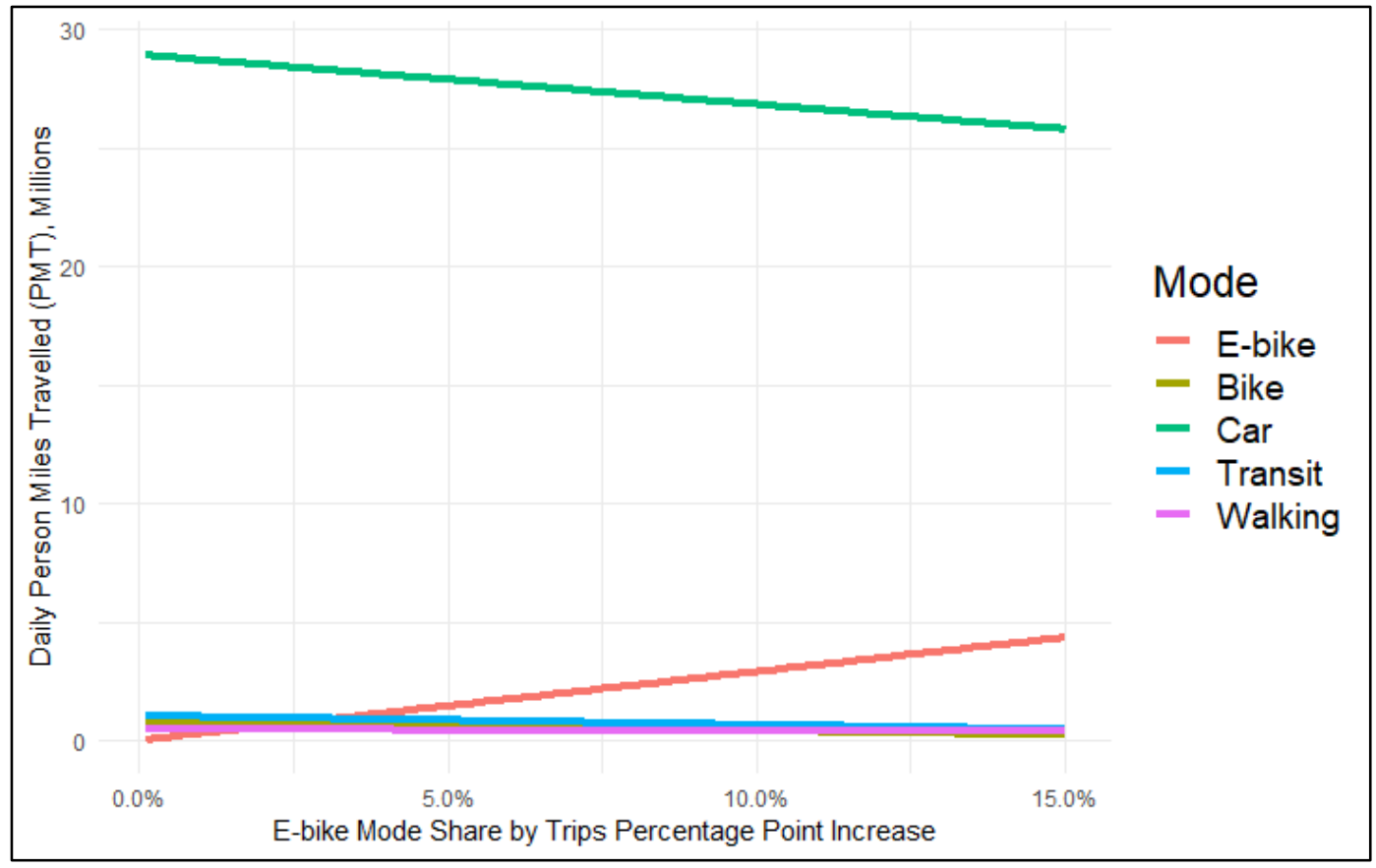

Figure 1: Person miles traveled (PMT) per e-bike mode share by trip percentage point increase 
Table 4: Person miles traveled per e-bike mode share by trip percentage point increase (values)

\begin{tabular}{|c|c|c|c|c|c|}
\hline ebikeMs & PMT_ebike & PMT_bike & PMT_car & PMT_transit & PMT_walking \\
\hline $1 \%$ & $2.89 \mathrm{E}+05$ & $7.09 \mathrm{E}+05$ & $2.87 \mathrm{E}+07$ & $9.89 \mathrm{E}+05$ & $4.54 \mathrm{E}+05$ \\
\hline $2 \%$ & $5.79 \mathrm{E}+05$ & $6.73 E+05$ & $2.85 \mathrm{E}+07$ & $9.51 \mathrm{E}+05$ & $4.48 \mathrm{E}+05$ \\
\hline $3 \%$ & $8.68 \mathrm{E}+05$ & $6.38 E+05$ & $2.83 \mathrm{E}+07$ & $9.13 E+05$ & $4.41 \mathrm{E}+05$ \\
\hline $4 \%$ & $1.16 \mathrm{E}+06$ & $6.03 E+05$ & $2.81 \mathrm{E}+07$ & $8.75 E+05$ & $4.35 \mathrm{E}+05$ \\
\hline $5 \%$ & $1.45 \mathrm{E}+06$ & $5.68 \mathrm{E}+05$ & $2.79 \mathrm{E}+07$ & $8.37 E+05$ & $4.28 \mathrm{E}+05$ \\
\hline $6 \%$ & $1.74 \mathrm{E}+06$ & $5.32 \mathrm{E}+05$ & $2.77 \mathrm{E}+07$ & $7.99 \mathrm{E}+05$ & $4.22 \mathrm{E}+05$ \\
\hline $7 \%$ & $2.03 \mathrm{E}+06$ & $4.97 \mathrm{E}+05$ & $2.75 \mathrm{E}+07$ & $7.61 \mathrm{E}+05$ & $4.15 \mathrm{E}+05$ \\
\hline $8 \%$ & $2.32 \mathrm{E}+06$ & $4.62 E+05$ & $2.73 \mathrm{E}+07$ & $7.23 E+05$ & $4.09 \mathrm{E}+05$ \\
\hline $9 \%$ & $2.60 \mathrm{E}+06$ & $4.27 E+05$ & $2.71 \mathrm{E}+07$ & $6.84 \mathrm{E}+05$ & $4.03 E+05$ \\
\hline $10 \%$ & $2.89 E+06$ & $3.92 E+05$ & $2.68 \mathrm{E}+07$ & $6.46 \mathrm{E}+05$ & $3.96 \mathrm{E}+05$ \\
\hline $11 \%$ & $3.18 \mathrm{E}+06$ & $3.56 \mathrm{E}+05$ & $2.66 \mathrm{E}+07$ & $6.08 \mathrm{E}+05$ & $3.90 \mathrm{E}+05$ \\
\hline $12 \%$ & $3.47 E+06$ & $3.21 E+05$ & $2.64 \mathrm{E}+07$ & $5.70 \mathrm{E}+05$ & $3.83 E+05$ \\
\hline $13 \%$ & $3.76 \mathrm{E}+06$ & $2.86 \mathrm{E}+05$ & $2.62 \mathrm{E}+07$ & $5.32 \mathrm{E}+05$ & $3.77 \mathrm{E}+05$ \\
\hline $14 \%$ & $4.05 E+06$ & $2.51 \mathrm{E}+05$ & $2.60 \mathrm{E}+07$ & $4.94 \mathrm{E}+05$ & $3.70 \mathrm{E}+05$ \\
\hline $15 \%$ & $4.34 \mathrm{E}+06$ & $2.15 E+05$ & $2.58 \mathrm{E}+07$ & $4.56 \mathrm{E}+05$ & $3.64 \mathrm{E}+05$ \\
\hline
\end{tabular}

\section{Carbon Emissions}

The model was developed to explore the case of Portland, Oregon. Based on current data and emissions profiles of the Portland metro region, on average, cars emit $274 \mathrm{~g} \mathrm{CO}_{2}$ per person mile (accounting for Portland average carpooling rates), public transit emits $140 \mathrm{~g} \mathrm{CO}_{2}$ per person mile (accounting for all Portland transit vehicle types), e-bikes emit $4.9 \mathrm{~g} \mathrm{CO}_{2}$ per person mile in the Northwest region (see Appendix Table 11), and conventional bicycles and walking emit $0 \mathrm{~g} \mathrm{CO}_{2}$ per person mile. Current total person miles traveled is 28,942,038 for cars, 1,027,342 for public transit, 743,837 for conventional bicycles, and 460,580 for walking. There is no data to separate out e-bikes from bicycle person mile figures, so an initial value of 0 PMT for e-bikes is assumed since e-bikes are currently in the early adopter phase.

From a GHG perspective, the model finds that a $15 \%$ point increase in e-bike mode share results in an $11 \%$ decrease in $\mathrm{CO}_{2}$ emissions, from 8,079 metric tons per day to 7,158 metric tons per day. Total emissions represented here are the sum of emissions from cars, transit, 
and e-bikes, however car emissions account for a large majority of this total $(98.8 \%$ of emissions can be attributed to cars at the $15 \%$ e-bike mode share case).

\section{Sensitivity Analysis}

For the model we chose to use an e-bike average trip length of 4.65 miles, half of the average trip length found in the MacArthur et al. 2018 survey to provide a conservative estimate. This resulted in $\mathrm{CO}_{2}$ savings of about 920 tons per day (an $11 \%$ decrease). If the full average trip length of 9.3 miles was used instead, there would be a $\mathrm{CO}_{2}$ savings of 1,800 tons per day (a $23 \%$ decrease).

On average, an e-bike will reduce an individual's emissions from transportation by 0.21 metric tons $\mathrm{CO}_{2}$ per year. However, this estimate is fairly conservative because it is based on Portland average regional values for mode share by trips and average trip length by mode. As seen in the North American Survey by MacArthur et al. (2018), e-bike users replaced utilitarian automobile trips with a mean length of 7.80 miles and a standard deviation of 6.79 miles, whereas the Portland mean trip length was only 5.49 miles. This means that for people with a similar transportation mode profile to the survey respondents that take up an e-bike, marginal emission reductions per person per year could range between .06 metric tons $\mathrm{CO}_{2}$ and .55 metric tons $\mathrm{CO}_{2}$ just by varying that person's average car trip length between the car trip length mean $+/-$ the standard deviation from the survey. This is calculated while holding the percentage of car trips that are replaced by e-bikes constant at $62.4 \%$.

Although an e-bike is a zero-emission vehicle, its ability to reduce carbon emissions is still dependent on the carbon cost of electricity generated within the operating region. This value ranges from $3.778 \mathrm{~g} \mathrm{CO}_{2}$ / e-bike mile within the AKMS subgrid, containing parts of Alaska, to $12.568 \mathrm{~g} \mathrm{CO}_{2}$ / e-bike mile within the MROE subgrid, containing parts of Wisconsin and Michigan (see Appendix Table 11). Portland falls towards the cleaner end of the spectrum at $4.905 \mathrm{~g} \mathrm{CO}_{2}$ / mile within the NWPP subgrid. Holding all other variables constant, setting the ebike emissions per mile rate to the worst value found in the United States (MROE) has a negligible effect on total emissions. This leaves the $11 \%$ decrease in $\mathrm{CO}_{2}$ for a $15 \%$ e-bike mode share by trips use case virtually unchanged. Thus, e-bike charging emission profiles are relatively unaffected by differences in power generation emission profiles within the United States. 


\section{LIMITATIONS}

This model does not take into account that there may be limits to mode share or person miles traveled reduction. It does not produce any asymptotic behavior as mode share or person miles traveled approach 0 for any mode. This means that the model is unable to account for a certain percentage of users of any mode that will not change modes under any circumstances. This manifests under certain initial conditions where total person miles traveled for a mode continues decreasing past zero. For example, using an e-bike average trip length of 9.3 miles, holding all other inputs constant, conventional bicycle miles traveled drop below zero at around $10.6 \%$ e-bike mode share. Transit person miles traveled drop below zero by $13.5 \%$ ebike mode share. However, walking miles traveled remain positive and automobile person miles traveled are still well above zero at the $15 \%$ mark. Figure 2 presents person miles traveled per e-bike mode share by trip percentage point increase with e-bike average trip length set to 9.3 miles.

Further research is needed to more accurately determine mode share distribution changes once any mode's miles traveled minimum is reached. However, transit and active transport make up such a small portion of the person miles traveled that continued decrease in automobile person miles traveled and corresponding emissions should still be within an acceptable order of magnitude. This specific case has been used to inform the emissions sensitivity analysis above.

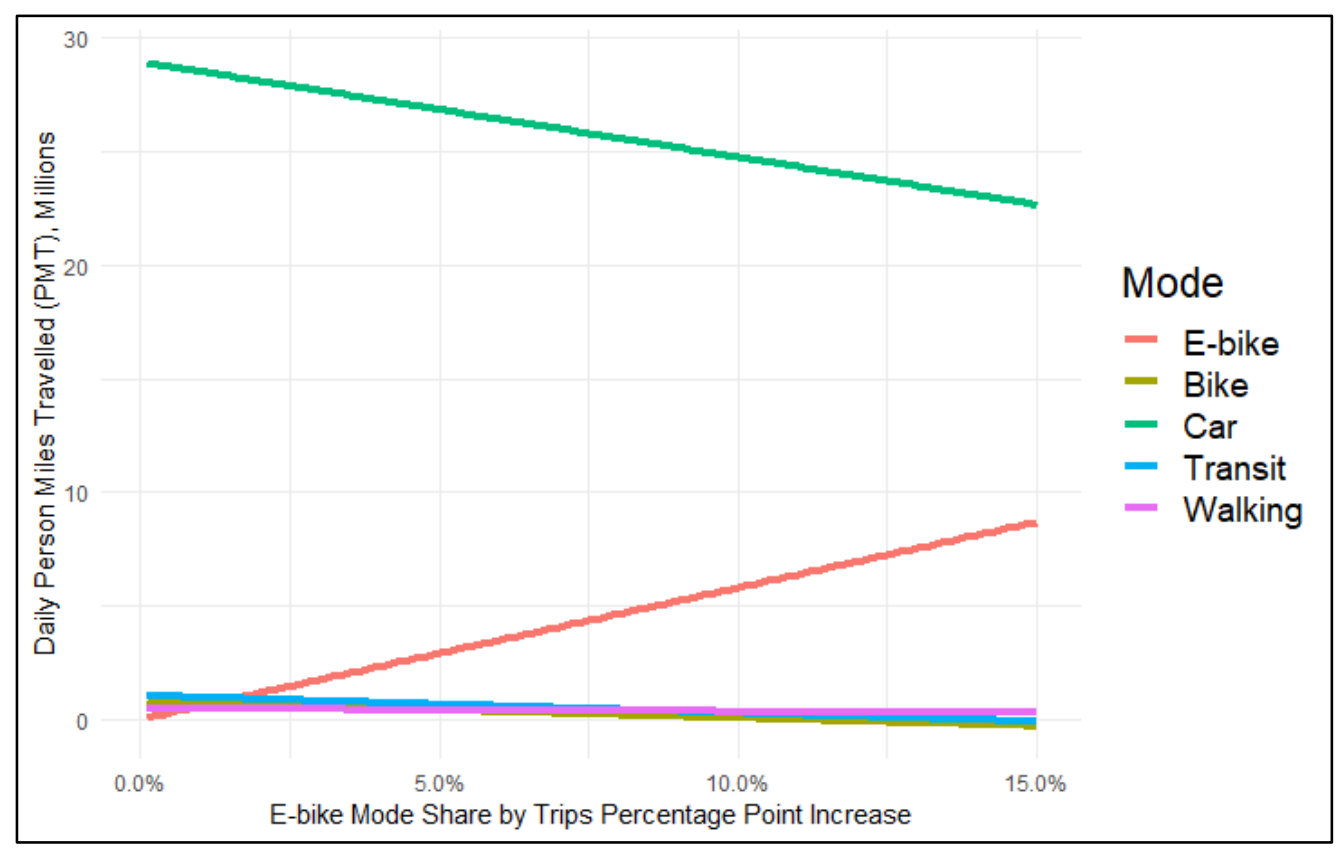

Figure 2: Person miles traveled per e-bike mode share by trip percentage point increase with e-bike average trip length set to 9.3 miles 
Another limitation is that vehicle miles traveled (VMT) is not recalculated from person miles traveled. The emissions calculations are simplified here by assuming that car and transit occupancy rates remain constant, preserving $\mathrm{g} \mathrm{CO}_{2}$ per person mile emission rates as e-bike mode share increases. Thus, if a transit agency does not adjust route schedules and number of vehicles on a transit line to accommodate lower ridership, occupancy rates would decrease leading to an increase in average $\mathrm{CO}_{2}$ emissions per person mile for transit riders. However, transit makes up such a small percent of person miles traveled that the effect on total emissions would be minimal. For instance, if average $\mathrm{CO}_{2}$ per transit person mile doubled due to decreased ridership and minimal route and fleet adjustments, total $\mathrm{CO}_{2}$ emissions for the region only increase by $1.8 \%$. Research may be necessary to further inform modeling the effects of lower transit ridership on emissions per transit person mile. 


\section{CONCLUSIONS}

Through applying trip replacement ratios, distance replacement ratios, and average e-bike trip length determined empirically for North America, car PMT and total transportation emissions in Portland, OR can be significantly reduced as e-bike mode share increases. This is on the order of a reduction in $\mathrm{CO}_{2}$ emissions of over 900 metric tons per day for a $15 \%$-point e-bike mode share by trips case (13.9\% in mode share by miles traveled), down $11 \%$ from Portland's current $\mathrm{CO}_{2}$ emissions of 8,000 metric tons per day. This is accomplished even while holding total person miles and trips constant. These findings are consistent with the $10 \%$ reduction in $\mathrm{CO}_{2}$ emissions found to correspond with a $14 \%$ combined bicycle and e-bike mode share in the global high shift cycling scenario (Mason, Fulton, and McDonald 2015). As demonstrated in the sensitivity analysis, this $11 \%$ reduction in $\mathrm{CO}_{2}$ emissions is maintained even when using the "dirtiest" electricity generation profile in the USA. The strategy of increasing e-bike mode share within a given region can therefore be used confidently as a tool to help meet that region's carbon emission reduction goals.

The question arises, however, about how a region can obtain the necessary e-bike mode share to bring about the desired carbon reduction effect. Existing research suggests implementing ebike subsidy programs and building infrastructure for charging and parking (Haubold 2016; Hiselius and Svensson 2017). In a recent white paper, the present authors have explored existing e-bike subsidy and incentive programs. This review can be used as a reference for developing future programs (McQueen, MacArthur, and Cherry 2019). Other research concludes that reducing vehicle speeds and volumes and building physically separated infrastructure can help to increase cycling (Buehler, Götschi, and Winters 2016). E-bike ridership could also be encouraged through implementation of a municipal e-bike share program, such as one piloted in Rostock Germany ("Elros Electric Mobility in Rostock" 2014).

Another method to increase e-bike mode share could be through a multi-modal approach. The Los Angeles County Metropolitan Transportation Authority recently used intercept surveys to study the GHG reduction benefit of trips that combined conventional bicycle and train modes ("Bicycle-Rail Trip Analysis and Greenhouse Gas Emissions Reduction Focused Study" 2011). A similar study focusing on e-bike/transit trips could be used as an impetus to fund new e-bike infrastructure at rapid transit stops in order to increase e-bike ridership among those requiring a first mile/last mile solution.

E-bikes offer regions a new opportunity to effectively diminish their transportation carbon footprint. Substantial political will and effort may be required, however, to seize it. The model 
presented here is useful for helping regions see this potential so that an informed decision can be made to include e-bike promotion as part of a larger suite of carbon emission reduction initiatives. 


\section{REFERENCES}

Anderson, Michael, and Ken McLeod. 2017. "Bike Commuting Growth Has Leveled Off - But Not Everywhere in the U.S." Streetsblog USA. September 14, 2017. https://usa.streetsblog.org/2017/09/14/bike-commuting-growth-has-leveled-off-but-noteverywhere-in-the-u-s/.

"Bicycle-Rail Trip Analysis and Greenhouse Gas Emissions Reduction Focused Study." 2011. Los Angeles County Metropolitan Transportation Authority.

Blondel, Benoît, Chloé Mispelon, and Julian Ferguson. 2011. "Cycle More Often 2 Cool down the Planet!: Quantifying CO2 Savings of Cycling." November 2011.

Buehler, Ralph, Thomas Götschi, and Meghan Winters. 2016. "Moving Toward Active Transportation: How Policies Can Encourage Walking and Bicycling." https://activelivingresearch.org/ActiveTravelreview.

Cairns, S., F. Behrendt, D. Raffo, C. Beaumont, and C. Kiefer. 2017. "Electrically-Assisted Bikes: Potential Impacts on Travel Behaviour." Transportation Research Part A: Policy and Practice 103 (September): 327-42. https://doi.org/10.1016/j.tra.2017.03.007.

"Elros Electric Mobility in Rostock." 2014. Rostocker Straßenbahn AG.

Fishman, Elliot, and Christopher Cherry. 2016. "E-Bikes in the Mainstream: Reviewing a Decade of Research.” Transport Reviews 36 (1): 72-91. https://doi.org/10.1080/01441647.2015.1069907.

Haubold, Holger. 2016. "ECF E for All."

Hiselius, Lena Winslott, and Åse Svensson. 2017. "E-Bike Use in Sweden - CO 2 Effects Due to Modal Change and Municipal Promotion Strategies." Journal of Cleaner Production 141 (January): 81824. https://doi.org/10.1016/j.jclepro.2016.09.141.

Jones, Tim, Lucas Harms, and Eva Heinen. 2016. "Motives, Perceptions and Experiences of Electric Bicycle Owners and Implications for Health, Wellbeing and Mobility." Journal of Transport Geography 53 (May): 41-49. https://doi.org/10.1016/j.jtrangeo.2016.04.006.

MacArthur, J., K. Clifton, J. Broach, and B. Shandobil. 2018. "Environmental and Equity Scenarios for Alternative Fuel Vehicle Ownership and Use in the Portland Region." https://doi.org/TREC-RR1167.

MacArthur, John, Michael Harpool, Daniel Schepke, and Christopher Cherry. 2018. "A North American Survey of Electric Bicycle Owners." Transportation Research and Education Center. https://doi.org/10.15760/trec.197.

MacArthur, John, Nicholas Kobel, Jennifer Dill, and Zakari Mumuni. 2017. "Evaluation of an Electric Bike Pilot Project."

Mason, Jacob, Lew Fulton, and Zane McDonald. 2015. "A Global High Shift Cycling Scenario: The Potential for Dramatically Increasing Bicycle and E-Bike Use in Cities Around the World, with Estimated Energy, CO2, and Cost Impacts." Institude for Transportation \& Development Policy, University of California, Davis. 
McQueen, Michael, John MacArthur, and Christopher Cherry. 2019. "How E-Bike Incentive Programs Are Used to Expand the Market: A White Paper." Transportation Research and Education Center.

Popovich, Natalie, Elizabeth Gordon, Zhenying Shao, Yan Xing, Yunshi Wang, and Susan Handy. 2014. "Experiences of Electric Bicycle Users in the Sacramento, California Area." Travel Behaviour and Society 1 (2): 37-44. https://doi.org/10.1016/j.tbs.2013.10.006.

Replogle, Michael A., and Lewis M. Fulton. 2014. "A Global High Shift Scenario: Impacts And Potential For More Public Transport, Walking, And Cycling With Lower Car Use." Institude for Transportation \& Development Policy, University of California, Davis.

Rudolph, Christian. 2014a. "Decreasing CO2 By Increasing Bicycle Use." Hamburg University of Technology (TUHH), Institute for Transport Planning and Logistics. http://www.mobile2020.eu/fileadmin/mainpage/downloads/co2tool/CO2_mobile2020.pdf.

- - . 2014b. "Mobile 2020 CO2 Estimation Tool." http://www.mobile2020.eu/fileadmin/mainpage/downloads/co2tool/CO2Tool_mobile2020_upload.xlsx.

Weiss, Martin, Peter Dekker, Alberto Moro, Harald Scholz, and Martin K. Patel. 2015. "On the Electrification of Road Transportation - A Review of the Environmental, Economic, and Social Performance of Electric Two-Wheelers." Transportation Research Part D: Transport and Environment 41 (December): 348-66. https://doi.org/10.1016/j.trd.2015.09.007. 


\section{APPENDIX}

\section{Region Specific Baseline Information}

Population and trip information for Portland was taken from Oregon Metro's 2018 Regional Transit Plan (RTP) Appendix I for the planning area excluding Clark County, WA. Trip information from the RTP is provided for average weekday (AWD) trips.

Table 5: City Information Input Definitions

\begin{tabular}{|l|l|l|c|l|}
\hline Category & Measure & Unit & Symbol & Source \\
\hline \multirow{4}{*}{$\begin{array}{l}\text { City } \\
\text { Information }\end{array}$} & Population & $\#$ & $p$ & RTP Appendix I \\
\cline { 2 - 5 } & $\begin{array}{l}\text { Avg weekday total } \\
\text { person trips }\end{array}$ & trips & $t$ & RTP Appendix I \\
\cline { 2 - 5 } & Avg trips per day & $\#$ per person & $\bar{t}_{d_{p}}$ & $\frac{t}{p}$ \\
\cline { 2 - 5 } & Avg trip length & miles/trip & $\bar{l}$ & RTP Appendix I \\
\hline
\end{tabular}

\section{Transportation Mode Details}

Table 6: Transportation Efficiency Input Definitions

\begin{tabular}{|c|c|c|c|c|}
\hline Category & Measure & Unit & Symbol & Source \\
\hline \multirow{6}{*}{ Details (car) } & $\mathrm{CO}_{2}$ per gal fuel & $\mathrm{g} \mathrm{CO}_{2} / \mathrm{gal}$ & $c_{c}$ & $\begin{array}{l}\text { eia.gov (carbon emissions for } \\
\text { E10) }\end{array}$ \\
\hline & Avg fuel economy & $\mathrm{mpg}$ & $\overline{\eta_{c}}$ & $\begin{array}{l}\text { Environmental and Equity } \\
\text { Scenarios for Alternative Fuel } \\
\text { Vehicle Ownership and Use } \\
\text { in the Portland Region } \\
\text { (MacArthur et al. 2018) }\end{array}$ \\
\hline & $\begin{array}{l}\text { AWD Passenger Vehicle } \\
\text { Person Trips }\end{array}$ & trips & $\bar{t}_{d p_{c}}$ & RTP Appendix I \\
\hline & $\begin{array}{l}\text { AWD Passenger Vehicle } \\
\text { Trips }\end{array}$ & trips & $\bar{t}_{d_{v_{c}}}$ & RTP Appendix I \\
\hline & Avg occupancy rate & $\begin{array}{l}\text { Person/vehi } \\
\text { cle }\end{array}$ & $\rho_{c}$ & $\frac{\bar{t}_{d_{p_{c}}}}{\bar{t}_{d_{v_{c}}}}$ \\
\hline & $\begin{array}{l}\text { Avg person fuel } \\
\text { economy }\end{array}$ & $\begin{array}{l}\text { Avg person } \\
\text { miles per } \\
\text { gallon }\end{array}$ & $\overline{\bar{\eta}_{c_{p}}}$ & $\rho_{c} * \overline{\eta_{c}}$ \\
\hline $\begin{array}{l}\text { Details (public } \\
\text { transit) }\end{array}$ & Avg emissions & $\begin{array}{l}\mathrm{g} \\
\mathrm{CO}_{2} / \text { person } \\
\text { miles }\end{array}$ & $\overline{c_{t_{p}}}$ & Calculated (see below) \\
\hline Details (e-bike) & $\begin{array}{l}\text { Avg emissions/mile (from } \\
\text { electricity generation in } \\
\text { NW region) }\end{array}$ & $\mathrm{g} \mathrm{CO}_{2} /$ mile & $\overline{\overline{c_{e_{l}}}}$ & $\begin{array}{l}\text { EPA eGrid: NWPP WECC } \\
\text { Northwest }\end{array}$ \\
\hline
\end{tabular}




\section{For public transit:}

Average emissions per person mile is calculated based on TriMet's (Portland's regional transit agency) mix of modes and fuel sources weighted by person miles traveled per mode. It makes use of the following data:

- Fuel Use: Federal Transit Administration Fuel and Energy data for fiscal year 2017

- Biodiesel is used both by bus and Westside Express Service (WES), so total biodiesel value given by FTA is split between Bus and WES according to person miles traveled ratio.

- Light rail (both Portland Streetcar and MAX) energy use contributions are provided separately by the FTA.

- PersonMiles: Federal Transit Administration Service data for fiscal year 2017

- Vehicle Miles: Federal Transit Administration Service data for fiscal year 2017

- Emissions per unit fuel: eia.gov for liquid fuels and Figliozzi et al. 2018 for Portland electricity generation emissions

- Total $\mathrm{g} \mathrm{CO}_{2}$ emitted per year: calculated

$$
\text { Total g CO } \mathrm{O}_{2}=\frac{\text { Fuel use }}{\text { Emissions per unit fuel }}
$$

- $\mathrm{g} \mathrm{CO}_{2}$ per personmile traveled (PMT): calculated

$$
\frac{g}{P M T}=\frac{\text { Total g } \mathrm{CO}_{2}}{\text { Passenger Miles }}
$$

- Average emissions per personmile: weighted average by PMT

$$
\operatorname{avg} \frac{g}{P M T}=\frac{\sum_{\text {mode }} \text { Passenger Miles } * \frac{g}{P M T}}{\sum_{\text {mode }} \text { Passenger Miles }}
$$


Table 7: Mode Specific Input Definitions

\begin{tabular}{|c|c|c|c|c|}
\hline Category & Measure & Unit & $\begin{array}{l}\text { Symb } \\
\text { ol }\end{array}$ & Source \\
\hline \multirow{5}{*}{ Modal Split } & $\%$ car trips & $\%$ & $\% t_{c}$ & \multirow[t]{4}{*}{ RTP Appendix I } \\
\hline & \% cycling trips & $\%$ & $\% t_{b}$ & \\
\hline & $\%$ public transit trips & $\%$ & $\% t_{t}$ & \\
\hline & $\%$ walking trips & $\%$ & $\% t_{w}$ & \\
\hline & \% e-bike trips & $\%$ & $\% t_{e}$ & Assumed 0 initially \\
\hline \multirow{5}{*}{$\begin{array}{l}\text { Modal } \\
\text { average } \\
\text { distance }\end{array}$} & Avg car trip length & miles & $\overline{l_{c}}$ & RTP Appendix I \\
\hline & Avg cycling trip length & miles & $\overline{l_{b}}$ & $\begin{array}{l}\text { RTP Appendix I } \\
\qquad \frac{A W D \text { Bike Miles Traveled }}{A W D \text { Total Bike Trips }}\end{array}$ \\
\hline & $\begin{array}{l}\text { Avg public transit trip } \\
\text { length }\end{array}$ & miles & $\overline{l_{t}}$ & $\begin{array}{l}\text { calculated as weighted average of transit } \\
\text { and paratransit trips from OHAS ODOT } \\
\text { Region } 1 \text { survey data }\end{array}$ \\
\hline & Avg walking trip length & miles & $\overline{l_{w}}$ & $\begin{array}{l}\text { calculated as weighted average of walking } \\
\text { trips from OHAS ODOT Region } 1 \text { survey } \\
\text { data }\end{array}$ \\
\hline & Avg e-bike trip length & miles & $\overline{l_{e}}$ & $\begin{array}{l}\text { A North American Survey of Electric Bicycle } \\
\text { Owners (MacArthur et al. 2018) - actual } \\
\text { value was } 9.3 \text { miles per trip, however to be } \\
\text { conservative, half this value was used ( } 4.65 \\
\text { miles) }\end{array}$ \\
\hline \multirow{4}{*}{$\begin{array}{l}\text { E-Bike } \\
\text { Mode } \\
\text { Replacemen } \\
\text { t Split by } \\
\text { trips }\end{array}$} & $\%$ car trips replaced & $\%$ & $\% r_{c}$ & \multirow{4}{*}{$\begin{array}{l}\text { A North American Survey of Electric Bicycle } \\
\text { Owners (MacArthur et al. 2018) }\end{array}$} \\
\hline & $\begin{array}{l}\text { \% cycling trips } \\
\text { replaced }\end{array}$ & $\%$ & $\% r_{b}$ & \\
\hline & $\begin{array}{l}\text { \% public transit trips } \\
\text { replaced }\end{array}$ & $\%$ & $\% r_{t}$ & \\
\hline & $\begin{array}{l}\% \text { walking trips } \\
\text { replaced }\end{array}$ & $\%$ & $\% r_{w}$ & \\
\hline \multirow{4}{*}{$\begin{array}{l}\text { E-Bike } \\
\text { Mode } \\
\text { Replacemen } \\
\text { t Split by } \\
\text { distance }\end{array}$} & $\begin{array}{l}\% \text { distance replaced } \\
\text { that was traveled by } \\
\text { car }\end{array}$ & $\%$ & $\% r_{l c}$ & \multirow[t]{4}{*}{$\begin{array}{l}\text { A North American Survey of Electric Bicycle } \\
\text { Owners (MacArthur et al. 2018) }\end{array}$} \\
\hline & $\begin{array}{l}\% \text { distance replaced } \\
\text { that was traveled by } \\
\text { cycling }\end{array}$ & $\%$ & $\% r_{l b}$ & \\
\hline & $\begin{array}{l}\text { \% distance replaced } \\
\text { that was traveled by } \\
\text { transit }\end{array}$ & $\%$ & $\% r_{l t}$ & \\
\hline & $\begin{array}{l}\% \text { distance replaced } \\
\text { that was traveled by } \\
\text { walking }\end{array}$ & $\%$ & $\% r_{l w}$ & \\
\hline
\end{tabular}




\section{E-Bike Mode Split}

Table 8: E-bike Input Definitions

\begin{tabular}{|l|l|l|c|l|}
\hline Category & Measure & Unit & Symbol & Source \\
\hline $\begin{array}{l}\text { Effects of e-bike } \\
\text { promotion }\end{array}$ & $\begin{array}{l}\text { Expected increase } \\
\text { of e-bike trips }\end{array}$ & $\%$ & $\% \Delta t_{e}$ & Test values \\
\cline { 2 - 5 } & $\begin{array}{l}\text { Expected increase } \\
\text { of average e-bike } \\
\text { trip length }\end{array}$ & $\%$ & $\% \Delta \overline{l_{e}}$ & Test values \\
\hline
\end{tabular}

\section{Assumptions:"}

- New mode share and new total person miles traveled is based on the mode and distance replacement data found in MacArthur et al. 2018.

- Number of trips and number of person miles traveled are held constant.

- E-bike trip lengths are expected to remain constant $\left(\% \Delta \overline{l_{e}}=0\right)$

- E-bike average trip length is half the value found in MacArthur et al. 2018 to test sensitivity $\left(\overline{l_{e}}=4.65\right)$

- Initial e-bike mode share by trips is $0 \%\left(\% t_{e}=0\right)$

- Mode share reduction of non-e-bike modes is linear and proportional to e-bike mode share increase (i.e., No asymptotic behavior simulated)

- Mode average trip length for modes other than e-bike are able to change, and is recalculated as $l_{n}^{\prime} / t_{n}^{\prime}$

- $\mathrm{CO}_{2}$ emissions are calculated using tank to wheel or electricity generation phase and does not use lifecycle emission rates (i.e., does not account for raw materials procurement, manufacture, maintenance, or disposal).

- Walking and biking are assumed to have zero greenhouse gas emissions.

- We exclude lifecycle impacts of marginal food production for all active modes.

- We exclude all recreation trip miles from analysis, focusing only on utilitarian miles traveled.

\section{Calculations:}

This section provides a pseudo code describing the method used to calculate PMT changes and GHG reductions. The same method is used by the excel tool and the $\mathrm{R}$ code, however the $\mathrm{R}$ code provides iterative functionality over a range of e-bike mode share values. 
Table 9: Mode split and distance traveled calculation definitions

\begin{tabular}{|c|c|c|c|c|}
\hline \multicolumn{5}{|c|}{ Effect of e-bike promotion } \\
\hline Measure & Mode & Calculation & Notes & $\begin{array}{l}\text { Unit } \\
\text { s }\end{array}$ \\
\hline \multirow{2}{*}{$\begin{array}{l}\text { Trips (total) for } \\
\text { each mode }\end{array}$} & $\begin{array}{l}\text { Car, public transit, } \\
\text { walking, cycling }\end{array}$ & \multirow{2}{*}{$t_{n}=p * \bar{t}_{d p} * \% t_{n}$} & & \multirow[t]{2}{*}{ trips } \\
\hline & E-bike & & & \\
\hline \multirow{2}{*}{$\begin{array}{l}\text { Travelled miles } \\
\text { (total) }\end{array}$} & $\begin{array}{l}\text { Car, public transit, } \\
\text { walking, cycling }\end{array}$ & \multirow{2}{*}{$l_{n}=t_{n} * \overline{l_{n}}$} & & \multirow[t]{2}{*}{ miles } \\
\hline & E-bike & & & \\
\hline \multirow{2}{*}{$\begin{array}{l}\text { Modal split \% by } \\
\text { travelled miles }\end{array}$} & $\begin{array}{l}\text { Car, public transit, } \\
\text { walking, cycling }\end{array}$ & \multirow{2}{*}{$\% l_{n}=\frac{l_{n}}{\sum l_{n}}$} & & \multirow[t]{2}{*}{$\%$} \\
\hline & E-bike & & & \\
\hline \multirow[t]{2}{*}{$\begin{array}{l}\text { New Modal Split } \\
\text { (by trips) }\end{array}$} & $\begin{array}{l}\text { Car, public transit, } \\
\text { walking, cycling }\end{array}$ & $\begin{array}{r}\% t_{n}^{\prime}=\% t_{n}-\% \Delta t_{e} \\
* \% r_{n}\end{array}$ & & $\%$ \\
\hline & E-bike & $\% t_{e}^{\prime}=\% t_{e}+\% \Delta t_{e}$ & & $\%$ \\
\hline \multirow{2}{*}{$\begin{array}{l}\text { New number of } \\
\text { trips }\end{array}$} & $\begin{array}{l}\text { Car, public transit, } \\
\text { walking, cycling }\end{array}$ & $t_{n}^{\prime}=\% t_{n}^{\prime} * t_{n}$ & & \multirow[t]{2}{*}{ trips } \\
\hline & E-bike & $t_{e}^{\prime}=\sum t_{n} * \% t^{\prime}{ }_{e}$ & & \\
\hline \multirow[t]{2}{*}{$\begin{array}{l}\text { Change in number } \\
\text { of trips }\end{array}$} & $\begin{array}{l}\text { Car, public transit, } \\
\text { walking, cycling }\end{array}$ & \multirow{2}{*}{$\Delta t_{n}=t_{n}^{\prime}-t_{n}$} & & \multirow[t]{2}{*}{ trips } \\
\hline & E-bike & & & \\
\hline \multirow[t]{2}{*}{$\begin{array}{l}\text { Average Trip } \\
\text { length new }\end{array}$} & $\begin{array}{l}\text { Car, public transit, } \\
\text { walking, cycling }\end{array}$ & $\overline{l_{n}^{\prime}}=\frac{l_{n}^{\prime}}{t_{n}^{\prime}}$ & & \multirow[t]{2}{*}{ miles } \\
\hline & E-bike & $\begin{array}{r}\overline{\bar{l}_{e}^{\prime}}=\left(\% \Delta \overline{l_{e}}+100 \%\right) \\
* \overline{l_{e}}\end{array}$ & & \\
\hline \multirow[t]{2}{*}{$\begin{array}{l}\text { Traveled Miles } \\
\text { new }\end{array}$} & $\begin{array}{l}\text { Car, public transit, } \\
\text { walking, cycling }\end{array}$ & $l_{n}^{\prime}=\% l_{n}^{\prime} * \sum l_{n}$ & & \multirow[t]{2}{*}{ miles } \\
\hline & E-bike & $l_{e}^{\prime}=t_{e}^{\prime} * \overline{l_{e}^{\prime}}$ & & \\
\hline \multirow{2}{*}{$\begin{array}{l}\text { New modal split } \\
\% \text { by travelled } \\
\text { miles }\end{array}$} & $\begin{array}{l}\text { Car, public transit, } \\
\text { walking, cycling }\end{array}$ & $\% l_{n}^{\prime}=\% l_{n}+\% \Delta l_{n}$ & & \multirow[t]{2}{*}{$\%$} \\
\hline & E-bike & $\% l_{e}^{\prime}=\frac{l_{e}^{\prime}}{\sum l_{n}}$ & $\begin{array}{l}\text { We can use } \sum l_{n} \\
\text { because total miles } \\
\text { traveled is conserved } \\
\text { between original and } \\
\text { new scenarios }\end{array}$ & \\
\hline \multirow{2}{*}{$\begin{array}{l}\text { Change in modal } \\
\text { split \% by } \\
\text { travelled miles }\end{array}$} & $\begin{array}{l}\text { Car, public transit, } \\
\text { walking, cycling }\end{array}$ & $\% \Delta l_{n}=\% \Delta l_{e} * \% r_{l n}$ & & \multirow[t]{2}{*}{$\%$} \\
\hline & E-bike & $\% \Delta l_{e}=\% l_{e}^{\prime}-\% l_{e}$ & & \\
\hline \multirow[t]{2}{*}{$\begin{array}{l}\text { Change in } \\
\text { travelled miles }\end{array}$} & $\begin{array}{l}\text { Car, public transit, } \\
\text { walking, cycling }\end{array}$ & \multirow[t]{2}{*}{$\Delta l_{n}=l_{n}^{\prime}-l_{n}$} & & \multirow[t]{2}{*}{ miles } \\
\hline & E-bike & & & \\
\hline
\end{tabular}




\section{Table 10: Total emissions calculation}

\begin{tabular}{|c|c|c|c|}
\hline \multicolumn{4}{|c|}{ Effects of e-bike promotion (Emissions) } \\
\hline Measure & Calculation & Notes & Units \\
\hline $\begin{array}{l}\text { Total carbon } \\
\text { emissions } \\
\text { from all } \\
\text { modes }\end{array}$ & $C=c_{c} * \frac{1}{\overline{\eta_{c}}} * \frac{1}{10^{6}} * l_{c}+l_{t} * \frac{\overline{c_{t_{p}}}}{10^{6}}+l_{e} * \frac{\overline{c_{e_{l}}}}{10^{6}}$ & $\begin{array}{l}\text { Walking and } \\
\text { conventional } \\
\text { cycling are } \\
\text { considered } 0 \\
\text { emission activities }\end{array}$ & $\frac{t C O 2}{d a y}$ \\
\hline $\begin{array}{l}\text { Total carbon } \\
\text { emissions } \\
\text { from all } \\
\text { modes - } \\
\text { Dimensional } \\
\text { Analysis } \\
\end{array}$ & $\begin{array}{l}\frac{t}{d a y}=\frac{g}{\text { gal }} * \frac{\text { gal }}{\text { person miles }} * \frac{t}{10^{6} g} * \text { person miles }+ \\
\text { person miles } * \frac{g}{\text { person miles }} * \frac{t}{10^{6} g}+\text { miles } * \frac{g}{\text { mile }} * \frac{t}{10^{6} g}\end{array}$ & & \\
\hline
\end{tabular}

First, calculate new total PMT by e-bike $l_{e}^{\prime}$

1. Calculate total travelled miles of all modes $\sum l_{n}$

2. Calculate e-bike new percent mode split by trips $\% t^{\prime}{ }_{e}$

a. Function of original e-bike percent mode split $\% t_{e}$ and e-bike expected percentage point change in mode split $\% \Delta t_{e}$

3. Calculate new number of e-bike trips $t^{\prime}{ }_{e}$

a. Function of sum of all trips $\sum t_{n}$ and the e-bike new percent mode split by trips $\% t^{\prime}$

4. Calculate new average e-bike trip length $\overline{l_{e}^{\prime}}$ (if trip length increase specified, can be left at 0)

a. Function of percent e-bike average trip length increase $\% \Delta \overline{l_{e}}$ and original e-bike average trip length $\bar{l}_{e}$

5. Calculate e-bike new total PMT $l_{e}^{\prime}$

a. Function of new average e-bike trip length $\overline{l^{\prime}} e_{e}$ and new number of e-bike trips $t_{e}^{\prime}$

Next, calculate new total PMT by mode $n$ (car, bike, walking, or transit)

1. Calculate original total miles traveled by e-bike $l_{e}$

a. Function of original number of e-bike trips $t_{e}$ and original e-bike average trip length $\bar{l}_{e}$

2. Calculate original total miles traveled by mode $\mathrm{n} l_{n}$

a. Function of original number of mode $\mathrm{n}$ trips $t_{n}$ and original mode $\mathrm{n}$ average trip length $\overline{l_{n}}$

3. Calculate the original modal split by travelled miles of e-bikes $\% l_{e}$

a. Function of original total miles traveled by e-bike $l_{e}$ and the sum of miles traveled by all modes $\sum l_{n}$

4. Calculate the original modal split by travelled miles of mode $\mathrm{n} \% l_{n}$ 
a. Function of original total miles traveled by mode $\mathrm{n} l_{n}$ and the sum of miles traveled by all modes $\sum l_{n}$

5. Calculate the new modal split by travelled miles of e-bikes $\% l_{e}^{\prime}$

a. Function of new total miles travelled by e-bike $l_{e}^{\prime}$ and sum of miles travelled by all modes $\sum l_{n}$

6. Calculate the change in modal split by travelled miles of e-bikes $\% \Delta l_{e}$

a. Function of new modal split by travelled miles of e-bikes $\% l_{e}^{\prime}$ and original modal split by travelled miles of e-bikes $\% l_{e}$

7. Calculate the change in modal split by travelled miles of mode $\mathrm{n} \% \Delta l_{n}$

a. Function of change in modal split by travelled miles of e-bikes $\% \Delta l_{e}$ and percent replaced miles for mode $\mathrm{n} \% r_{l n}$

8. Calculate new modal split by travelled miles of mode $\mathrm{n} \% l^{\prime}{ }_{n}$

a. Function of original modal split by travelled miles of mode $\mathrm{n} \% l_{n}$ and change in modal split by travelled miles of mode $\mathrm{n} \% \Delta l_{n}$

9. Calculate new traveled miles of mode $\mathrm{n} l_{n}^{\prime}$

a. Function of new modal split by travelled miles of mode $n \% l_{n}^{\prime}$ and sum of miles travelled by all modes $\sum l_{n}$

\section{Lastly, calculate emissions}

1. Calculate the total daily carbon emissions of passenger transportation sector $C$

a. Function of $\mathrm{CO}_{2}$ per gallon of car fuel $c_{c}$, average person fuel economy $\bar{\eta}_{c_{p}}$, total distance traveled by cars $l_{c}^{\prime}$, total distance traveled by transit $l_{t}^{\prime}$, average $\mathrm{CO}_{2}$ per transit person mile $\overline{c_{t_{p}}}$, total distance traveled by e-bikes $l_{e}^{\prime}$, and average $\mathrm{CO}_{2}$ per e-bike mile $\overline{c_{e_{l}}}$ 


\section{Additional Results Figures}

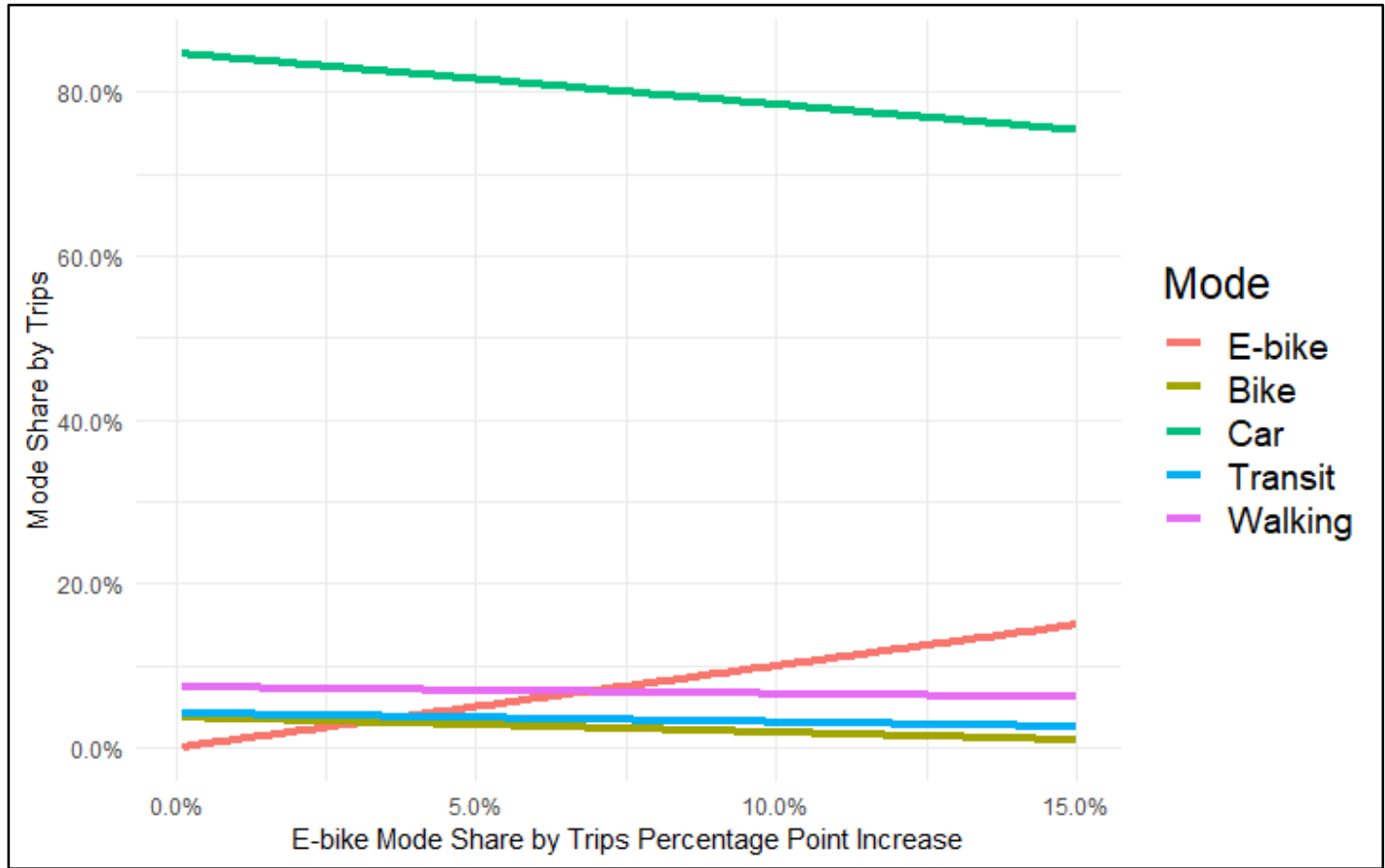

Figure 3: Mode share by trips (MST) change per e-bike mode share by trip percentage point increase

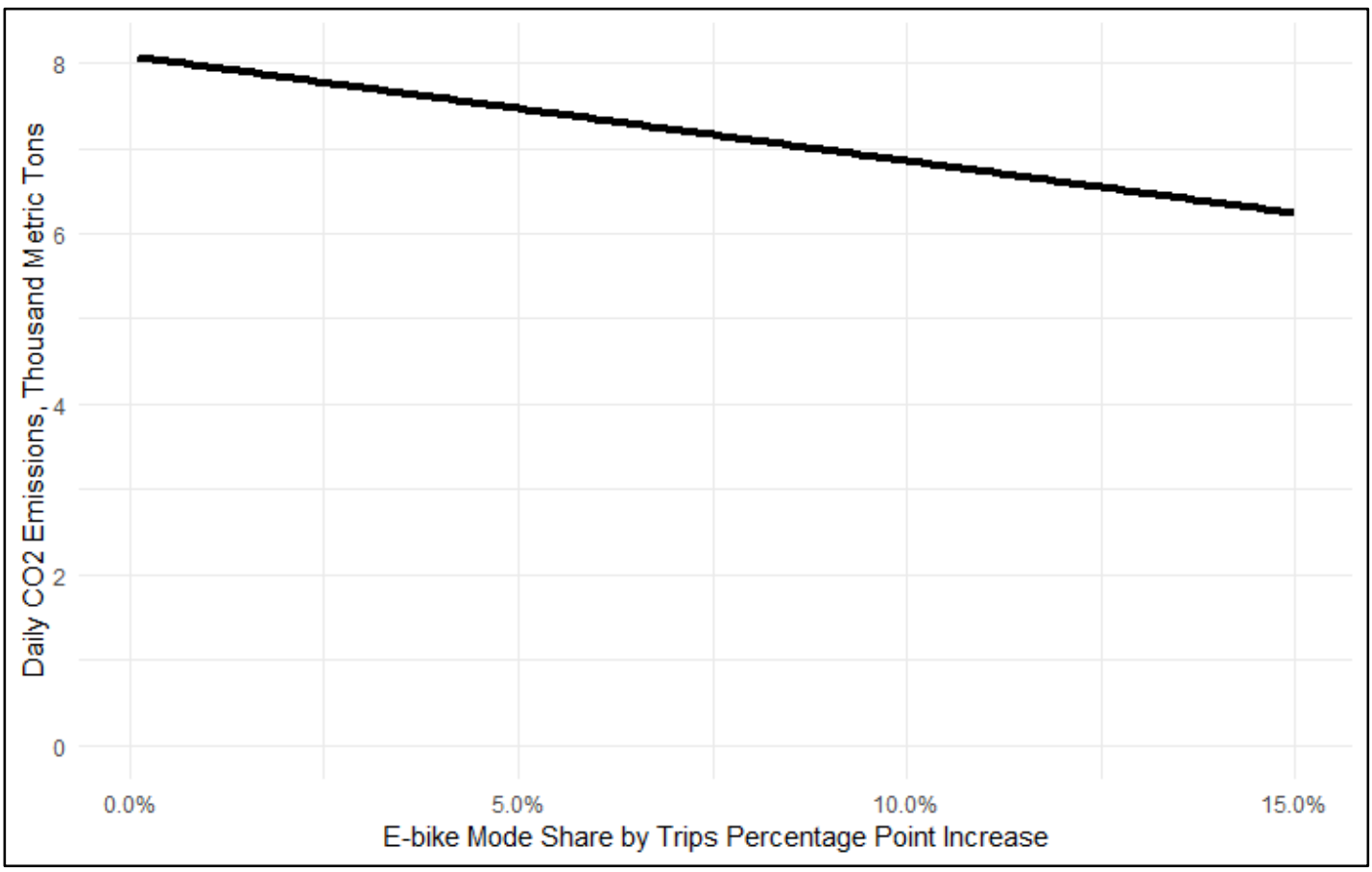

Figure 4: $\mathrm{CO}_{2}$ emissions change per e-bike mode share by trip percentage point increase 


\section{Reference}

Table 11 contains estimates of the average g CO2 per mile "emission" rates for e-bikes based on location. Each location in the table corresponds with a region on the map in Figure 5 . Ebikes do not emit $\mathrm{CO} 2$ themselves, however the power generation plants that supply the electricity to charge the battery do, and thus a carbon cost of e-bike distance traveled can be calculated (albeit small compared to automobiles). This value varies by region because each subregion uses a unique mixture of fuel sources. Portland falls within the NWPP subregion.

Table 11: E-bike Emissions Rate by Power Generation Subregion (EPA e-grid)

\begin{tabular}{|l|l|l|}
\hline Acronym & Subregion Name & Emission Rate $\left(\mathbf{g ~ C O}_{2} / \mathbf{m i l e}\right)$ \\
\hline AKGD & ASCC Alaska Grid & 8.063 \\
\hline AKMS & ASCC Miscellaneous & 3.778 \\
\hline AZNM & WECC Southwest & 7.851 \\
\hline CAMX & WECC California & 3.966 \\
\hline ERCT & ERCOT All & 7.59 \\
\hline FRCC & FRCC All & 7.607 \\
\hline HIMS & HICC Miscellaneous & 8.672 \\
\hline HIOA & HICC Oahu & 12.538 \\
\hline MROE & MRO East & 12.568 \\
\hline MROW & MRO West & 9.336 \\
\hline NEWE & NPCC New England & 4.219 \\
\hline NWPP & WECC Northwest & 4.905 \\
\hline NYCW & NPCC NYC/Westchester & 4.768 \\
\hline NYLI & NPCC Long Island & 8.876 \\
\hline NYUP & NPCC Upstate NY & 2.215 \\
\hline RFCE & RFC East & 5.704 \\
\hline RFCM & RFC Michigan & 9.572 \\
\hline RFCW & RFC West & 9.366 \\
\hline RMPA & WECC Rockies & 10.304 \\
\hline SPNO & SPP North & 10.644 \\
\hline SPSO & SPP South & 9.392 \\
\hline SRMV & SERC Mississippi Valley & 6.303 \\
\hline SRMW & SERC Midwest & 12.143 \\
\hline SRSO & SERC South & 8.196 \\
\hline SRTV & SERC Tennessee Valley & 8.926 \\
\hline SRVC & SERC Virginia/Carolina & 6.063 \\
\hline & & \\
\hline & & \\
\hline
\end{tabular}




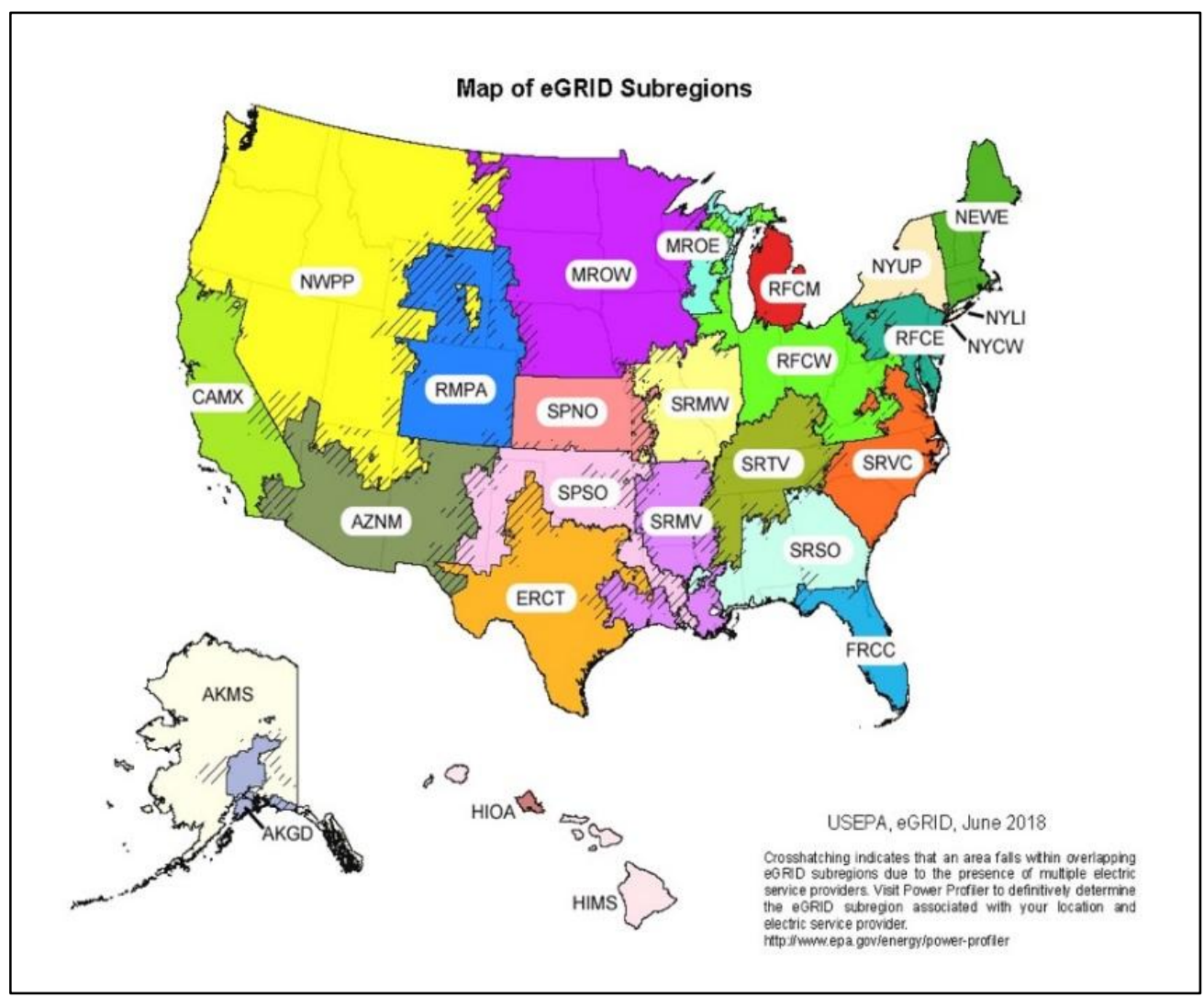

Figure 5: United States Power Generation Subregions (eGRID) 